\title{
Recovery of Silver from Cyanide Solutions Using Electrochemical Process Like Alternative for Merrill-Crowe Process
}

\author{
Víctor Vázquez¹, José Parga², Jesús L. Valenzuela', Gabriela Figueroa1, \\ Alejandro Valenzuela1, Guillermo Munive ${ }^{1}$ \\ ${ }^{1}$ Department of Chemical Engineering and Metallurgy, University of Sonora, Hermosillo, Mexico \\ ${ }^{2}$ Department of Materials Science and Metallurgy, Technological Institute of Saltillo, Saltillo, Mexico \\ Email: victor.vazquez@iq.uson.mx
}

Received 26 June 2014; revised 20 August 2014; accepted 10 September 2014

Copyright (C) 2014 by authors and Scientific Research Publishing Inc.

This work is licensed under the Creative Commons Attribution International License (CC BY). http://creativecommons.org/licenses/by/4.0/

(c) (i) Open Access

\begin{abstract}
The conventional processes for recovery of silver from cyanide leach solutions are the carbon adsorption, the Merrill-Crowe zinc dust cementation, the Ion Exchange, and Solvent Extraction processes; among other available options for recovery of precious metals from cyanide solutions, Electrocoagulation (EC) is a very promising electrochemical process that does not require high concentrations of silver in cyanide solutions to yield excellent results and neither pretreatment of cyanide solutions like Merrill-Crowe process (deoxygenating and clarification). The present study has been done for the recovery of silver contained in pregnant solution from the cyanidation process using the electrocoagulation technology with iron electrodes, and therefore develops an alternative technology for Merril-Crowe process. The average silver content in pregnant solution was of $52 \mathrm{ppm}$, recovery was obtained of $99 \%$ of silver, with this optimum operating parameters, $\mathbf{p H}=8$, residence time $=20$ minutes and conductivity by addition of sodium chloride $=4 \mathrm{grs} / \mathrm{L}$. Finally the characterization of the solid products formed during the EC process with X-ray Diffraction and Scanning Electronic Microscope was performed, results suggest that magnetite particles and amorphous iron oxyhydroxides are present (Lepidocrocite).
\end{abstract}

\section{Keywords}

Electrochemical Process, Silver, Cyanides, Magnetic Fields, Merrill-Crowe

\section{Introduction}

Cyanidation processes are especially suitable for treatment of silver-bearing sulphidic materials. Modern hy-

How to cite this paper: Vázquez, V., Parga, J., Valenzuela, J.L., Figueroa, G., Valenzuela, A. and Munive, G. (2014) Recovery of Silver from Cyanide Solutions Using Electrochemical Process Like Alternative for Merrill-Crowe Process. Materials Sciences and Applications, 5, 863-870. http://dx.doi.org/10.4236/msa.2014.512087 
drometallurgy technology of precious metals is based on the application of cyanide leaching for the dissolution of silver. Silver cyanidation has been reported to involve the chemical reactions shown in Equations (1) and (2).

$$
\begin{gathered}
2 \mathrm{Ag}+4 \mathrm{NaCN}+\mathrm{O}_{2}+2 \mathrm{H}_{2} \mathrm{O} \rightarrow 2 \mathrm{Na}\left[\mathrm{Ag}(\mathrm{CN})_{2}\right]+2 \mathrm{NaOH}+\mathrm{H}_{2} \mathrm{O}_{2} \\
2 \mathrm{Ag}+4 \mathrm{NaCN}+\mathrm{H}_{2} \mathrm{O}_{2} \rightarrow 2 \mathrm{Na}\left[\mathrm{Ag}(\mathrm{CN})_{2}\right]+2 \mathrm{NaOH}
\end{gathered}
$$

Later work, however, showed that the first equation was the most important during leaching. The stoichiometry of the process shows that 4 moles of cyanide are needed for each mole of oxygen present in solution. At room temperature and atmospheric pressure, approximately $8.2 \mathrm{mg}$ of oxygen is present in one liter of water corresponding to $0.27 \times 10^{-3} \mathrm{~mol} / \mathrm{L}$. Accordingly, the sodium cyanide concentration (molecular weight of NaCN $=49$ ) should be equal to $4 \times 0.27 \times 10^{-3} \times 49=0.05 \mathrm{~g} / \mathrm{L}$ or approximately $0.01 \%$. This was confirmed in practice at room temperature by a very dilute solution of $\mathrm{NaCN}$ of $0.01 \%-0.5 \%$ for ores and for concentrates rich in silver $0.5 \%-5 \%$ [1]. Also, details of this electrochemical reaction have received considerable attention and under certain circumstances the reaction is limited by the coupled diffusion of $\mathrm{CN}^{-}$and $\mathrm{O}_{2}$ to the gold surface. Lime or sodium hydroxide (caustic) is added to keep the system at an alkaline $\mathrm{pH}$ of $10^{-11}$. This protective alkalinity is required to counteract the generation of acid during cyanidation, thereby preventing cyanide degradation and the formation of the deadly HCN gas [2].

Currently, the two conventional processes for silver recovery from cyanide leach solution are the carbon adsorption process and the Merrill-Crowe zinc dust cementation process. In the first, the precious metals are absorbed onto granules of activated carbon, after loading, they are then stripped off the loaded silver by a hot caustic cyanide solution [3]. This solution is in turn fed to electrowinning cells where the gold and silver are electrolytically deposited onto cathodes of steel wool. In the second case, the Merrill-Crowe product is filtered zinc dust precipitate. The cathodes from the carbon adsorption process or the precipitates from the Merrill-Crowe process (Metal displacements) are then melted in crucible furnaces along with fluxing materials such as borax, niter, and silica. The resultant product from smelting is Dore bullion of precious metals typically analyzing more than 97 percent of precious metals [4].

Each recovery method has advantages and disadvantages. Process selection depends on the specific conditions for a particular operation and the facilities already available. The Merrill-Crowe method had been the preferred process for many years; only recently in the past 40 years has the carbon adsorption process become popular for recovering gold from large volumes of low grade pregnant leach solutions that contain mainly gold.

The EC process is a very promising technique in the recovery of precious metals such as silver and gold: EC needs no chemical reagents, does not generate toxic materials of cyanide requiring special disposal and this also makes it an ecologically viable technique. Reviewing of the literature makes it clear that the potential of EC as an alternative to traditional treatment recovery of precious metals (silver and gold cyanide) has not yet been exploited. Other method that has been tried for the recovery of gold and silver is adsorption on a chemically modified chitosan with magnetic properties [5].

\subsection{Merrill-Crowe Process}

The zinc cementation process was introduced in 1890's and became an important part of the cyanidation process. C. W. Merrill as mentioned in the introduction was the first to use the application of the zinc cementation process at the Homestake Mine in Lead South Dakota in 1897 [6]. In 1918, the vacuum de-aeration tank was introduced by T.B. Crowe and was incorporated into the Merrill process to make the Merrill-Crowe process. This was the removal of dissolved oxygen, which caused zinc passivation making it almost impossible to filter [8]. Main reactions are the deposition of silver on the surfaces of zinc particles. There are two half-cell reactions representing this, the first one being the reduction of silver by zinc.

$$
\mathrm{Ag}(\mathrm{CN})_{2}^{-}+\mathrm{e}^{-} \rightarrow \mathrm{Ag}+2 \mathrm{CN}^{-}(\text {primary reaction })
$$

\subsection{Electrocoagulation Characteristic}

The EC process operates on the principle that the cations produced electrolytically from iron and/or aluminum anodes enhance the coagulation of contaminants from an aqueous medium. The sacrificial metal anodes are used to continuously produce polyvalent metal cations in the vicinity of the anode [7]. These cations facilitate coagu- 
lation by neutralizing the negatively charged particles that are carried toward the anodes by electrophoretic motion. In the flowing EC techniques, the production of polyvalent cations from the oxidation of the sacrificial anodes $(\mathrm{Fe}$ and/or $\mathrm{Al})$ and the production of electrolysis gases $\left(\mathrm{O}_{2}\right.$ and/or $\left.\mathrm{H}_{2}\right)$ are directly proportional to the amount of current applied (Faraday's law). The electrolysis gases enhance the flocculation of the coagulant materials. Passage of an alternating current at an inert electrode, such as titanium, has also been observed to remove metal ions from solution and to initiate the coagulation of suspended solids [8].

A schematic representation of the EC process is shown in Figure 1. As mentioned above, the gas bubbles produced by the electrolysis carry the pollutant to the top of the solution where it is concentrated, collected and removed. The removal mechanisms in EC may involve oxidation, reduction, decomposition, deposition, coagulation, absorption, adsorption, precipitation and flotation.

However, it is the reactions of the metal ions that enhance the formation of the coagulant. The metal cations react with the $\mathrm{OH}^{-}$ions produced at the cathode (see Equation (6)) during the evolution of hydrogen, to yield both soluble and insoluble hydroxides that will react with or adsorb silver, from the cyanide solution and also contribute to coagulation by neutralizing the negatively charged colloidal particles that may be present at neutral or alkaline $\mathrm{pH}$. This enables the particles to approach closely and agglomerate under the influence of Van der Waals attractive forces. The chemical reactions that have been proposed to describe EC mechanisms for the production of $\mathrm{H}_{2(\mathrm{~g})}, \mathrm{OH}_{(\mathrm{aq})}^{-}$(cathode) and $\mathrm{H}_{(\mathrm{aq})}^{+}$and $\mathrm{O}_{2(\mathrm{~g})}$ (anode) [9] are:

Anode:

$$
\begin{aligned}
\mathrm{aM}_{(\mathrm{s})} & \rightarrow \mathrm{aM}^{\mathrm{n}+}+\mathrm{an}\left(\mathrm{e}^{-}\right) \\
2 \mathrm{H}_{2} \mathrm{O} & \rightarrow \mathrm{O}_{2}+4 \mathrm{H}^{+}+4 \mathrm{e}^{-}
\end{aligned}
$$

Cathode:

$$
\begin{gathered}
\text { an }\left(\mathrm{H}_{2} \mathrm{O}\right)+\operatorname{an}\left(\mathrm{e}^{-}\right) \rightarrow \frac{\text { an }}{2} \mathrm{H}_{2}+\operatorname{an}\left(\mathrm{OH}^{-}\right) \\
4 \mathrm{H}^{+}+4 \mathrm{e}^{-} \rightarrow 2 \mathrm{H}_{2}
\end{gathered}
$$

Overall:

$$
\mathrm{aM}_{(\mathrm{s})}+(2+\mathrm{an}) \mathrm{H}_{2} \mathrm{O} \rightarrow\left(2+\frac{\mathrm{an}}{2}\right) \mathrm{H}_{2}+\mathrm{O}_{2}+\mathrm{an}\left(\mathrm{OH}^{-}\right)+\mathrm{aM}^{\mathrm{n}+}
$$

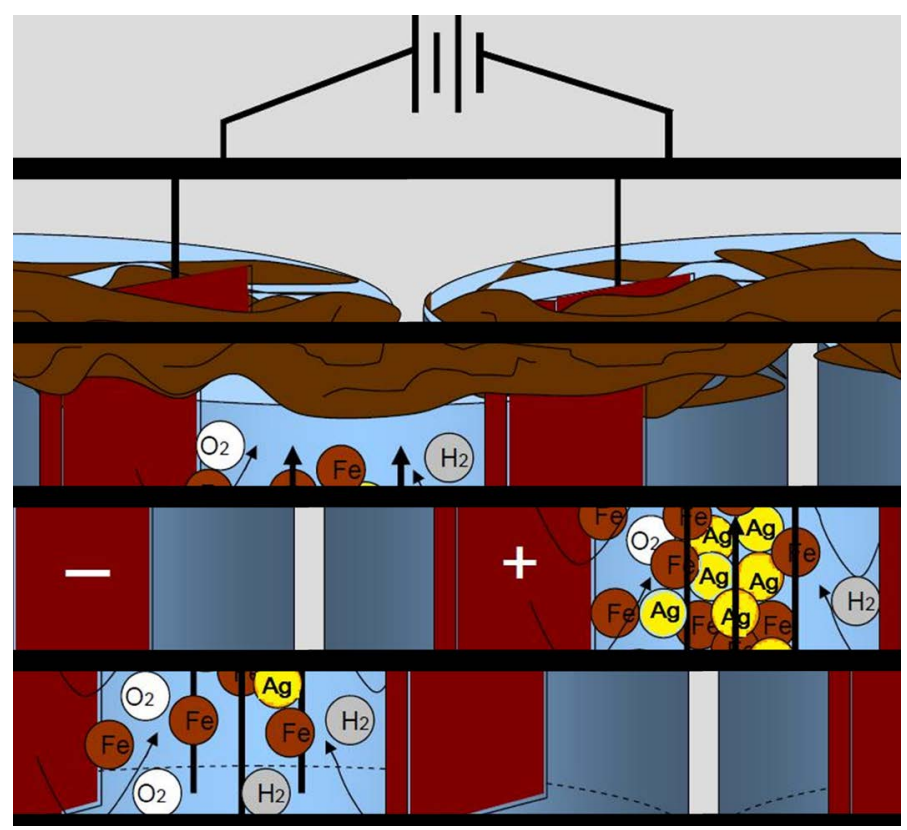

Figure 1. EC process. 
When $\mathrm{M}_{(\mathrm{s})}=$ Fe metal electrode

$$
\begin{array}{ll}
\mathrm{Fe}_{(\mathrm{s})} \rightarrow \mathrm{Fe}^{2+}+2 \mathrm{e}^{-} & \mathrm{E}^{\mathrm{o}}=-0-44 \mathrm{v} \\
\mathrm{Fe}^{2+} \rightarrow \mathrm{Fe}^{3+}+\mathrm{e}^{-} & \mathrm{E}^{0}=0.77 \mathrm{v} \\
\mathrm{Fe}_{(\mathrm{s})} \rightarrow \mathrm{Fe}^{3+}+3 \mathrm{e}^{-} & \mathrm{E}^{0}=-0.04 \mathrm{v}
\end{array}
$$

where constant a is a stoichiometric coefficient, and $\mathrm{n}$ is the number of electrons involved. The $\mathrm{pH}$ of the medium usually rises as a result of this electrochemical process and the $\mathrm{Fe}(\mathrm{OH})_{\mathrm{n}(\mathrm{s})}$ formed remains in the aqueous stream as a gelatinous suspension, which can remove the gold and silver from pregnant cyanide rich solutions, either by complexation or by electrostatic attraction followed by coagulation and flotation. Thus it is evident that maghemite is formed during electrolysis by utilizing oxygen:

$$
4 \mathrm{Fe}(\mathrm{OH})_{2(\mathrm{~s})}+\mathrm{O}_{2(\mathrm{aq})} \rightarrow 2 \mathrm{Fe}_{2} \mathrm{O}_{3(\mathrm{~s})+} 4 \mathrm{H}_{2} \mathrm{O}
$$

Generally in the EC process bipolar electrodes are used [10]. It has been reported that cells with bipolar electrodes connected in series operating at relatively low current densities produced iron or aluminum coagulant more effectively.

\section{Experimental Detail}

The Electrocoagulation experiments were performed in a $600 \mathrm{ml}$ beaker size reactor equipped with two carbon steel electrodes $(10 \mathrm{~cm} \times 5 \mathrm{~cm})$ that were $5 \mathrm{~mm}$ apart (see Figure 2). As a source of current and voltage a universal AC/DC adaptor was used. $\mathrm{pH}$ was measured with a VWR scientific $8005 \mathrm{pH}$ meter. The pregnant cyanide solutions were provided by the William mining group S.A. de C.V. with average silver concentration of $55 \mathrm{ppm}$.

The conductivity of pregnant solution was adjusted by adding two, three and four grams of $\mathrm{NaCl}$ per liter (Fisher, 99.8\% A.C.S. Certified, lot \#995007). The $\mathrm{pH}$ was adjusted using a solution of sulfuric acid $0.1 \mathrm{M}$. EC was run on the samples, solutions and solids from the process were then separated by filtration through cellulose filter paper. The sludge from the EC was dried either in an oven or under vacuum at room temperature.

In order to find the optimum parameters of the EC process for recovery of silver, experiments were conducted by changing voltage and amperage, $\mathrm{pH}$ of the solution, and residence time in the EC cell, the silver initial concentration and the operational parameters are listed in Table 1, Table 2 and Table 3.

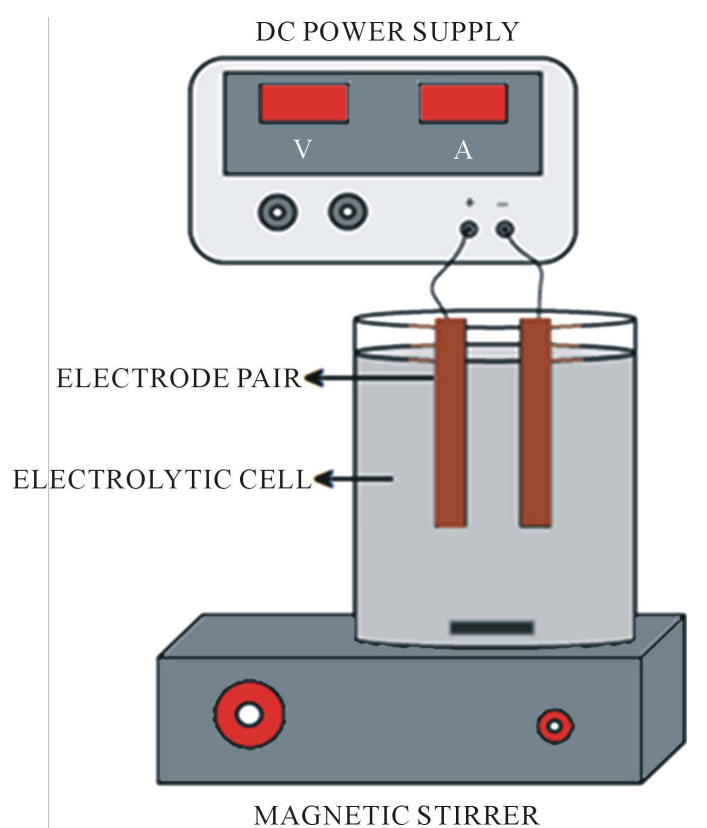

Figure 2. Squematic diagram of electrocoagulation test. 
Table 1. Initial Operating conditions of electrocoagulation (2 grs $\mathrm{NaCl})$.

\begin{tabular}{cccc}
\hline \multicolumn{4}{c}{$45 \mathrm{ppm}, \mathrm{pH} 8$} \\
\hline Time (min) & Voltage (volt) & Current (A) & Volume (ml) \\
\hline 5 & 19 & 22 & 500 \\
10 & 20 & 23 & 500 \\
15 & 18 & 20 & 500 \\
20 & 18 & 21 & 500 \\
\hline
\end{tabular}

Table 2. Initial Operating conditions of electrocoagulation (4 grs $\mathrm{NaCl})$.

\begin{tabular}{cccc}
\hline \multicolumn{4}{c}{$60 \mathrm{ppm}, \mathrm{pH} 8$} \\
\hline Time (min) & Voltage (volt) & Current (A) & Volume (ml) \\
\hline 5 & 18 & 20 & 500 \\
10 & 20 & 22 & 500 \\
15 & 19 & 21 & 500 \\
20 & 19 & 22 & 500 \\
\hline
\end{tabular}

Table 3. Initial Operating conditions of electrocoagulation (4 grs $\mathrm{NaCl})$.

\begin{tabular}{cccc}
\hline \multicolumn{4}{c}{55 ppm, pH 8} \\
Time (min) & Voltage (volt) & Current (A) & Volume (ml) \\
\hline 5 & 18 & 20 & 500 \\
10 & 20 & 22 & 500 \\
15 & 19 & 21 & 500 \\
20 & 19 & 22 & 500 \\
\hline
\end{tabular}

\section{Results}

With this parameters the EC process gave the results shown in Table 4, Table 5 and Table 6 and Figure 5 shows the $\mathrm{pH}$ behavior vs. Time.

From this results we can determine that, when residence time increases from 10 to 15 minutes the recoveries of silver increase respectively from $37 \%$ to $77 \%$, for 2 grs of $\mathrm{NaCl}$, from $40 \%$ to $73.33 \%$ for 3 grs of $\mathrm{NaCl}$ and from $48.88 \%$ to $80 \%$ up to $99 \%$ for 4 grs of $\mathrm{NaCl}$, this occurs in the $\mathrm{pH}$ range from 9 to 10 approximately, that coincides with the production of magnetic iron, $\mathrm{Fe}_{3} \mathrm{O}_{4}$, which has magnetic properties that accelerates the process of adsorption of precious metals.

The EC process for silver recovery is then physical adsorption, because it is caused by the magnetic forces of the magnetite into silver. We can determine too, what increase $\mathrm{NaCl}$ concentration the current density rises, increment the interaction between silver and magnetic iron particles. These forces do not alter their chemical composition. Figure 3 also shows graphically the $\mathrm{pH}$ change during the EC the process, this $\mathrm{pH}$ increment in the solution is likely attributed to the hydrogen evolution at the cathode which is accompanied by alkalinization of the aqueous solution. The final effect is the oxidation suffered by the anode coupled with the generation of hydroxyl iron ions generated during EC process.

\subsection{Product Characterization}

To identify the iron species, X-ray diffraction (XRD) and Scanning Electron Microscope (SEM/EDX) were carried out to characterize the solid products formed during the EC process for recovery of silver which uses iron electrodes. 
Table 4. Results for 2 grs of $\mathrm{NaCl}$.

\begin{tabular}{cccc}
\hline Time $(\mathrm{min})$ & {$[\mathrm{Ag}](\mathrm{ppm})$} & Recovery \% & $\mathrm{pH}$ \\
\hline 0 & 45 & 0 & 8 \\
5 & 36 & 20 & 9.2 \\
10 & 28 & 37.78 & 9.5 \\
15 & 10 & 77.78 & 10.2 \\
20 & 0.5 & 98.88 & 10.7 \\
\hline
\end{tabular}

Table 5. Results for 3 grs of $\mathrm{NaCl}$.

\begin{tabular}{cccc}
\hline Time (min) & {$[\mathrm{Ag}](\mathrm{ppm})$} & Recovery \% & $\mathrm{pH}$ \\
\hline 0 & 60 & 0 & 8 \\
5 & 52 & 17.78 & 9.5 \\
10 & 42 & 40 & 9.9 \\
15 & 12 & 73.33 & 10.5 \\
20 & 0.4 & 99.11 & 11.3 \\
\hline
\end{tabular}

Table 6. Results for 4 grs of $\mathrm{NaCl}$.

\begin{tabular}{cccc}
\hline Time $(\min )$ & {$[\mathrm{Ag}](\mathrm{ppm})$} & Recovery $\%$ & $\mathrm{pH}$ \\
\hline 0 & 55 & 0 & 8 \\
5 & 43 & 26.67 & 8.6 \\
10 & 33 & 48.88 & 9.1 \\
15 & 9 & 80 & 10.3 \\
20 & 0.2 & 99.6 & 11.1 \\
\hline
\end{tabular}

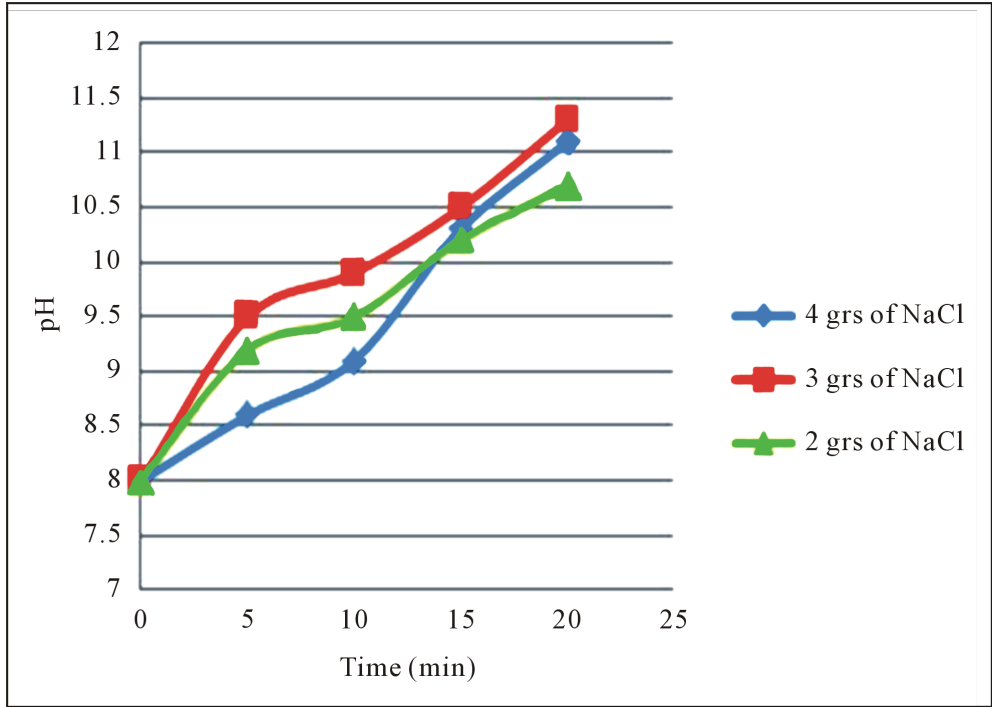

Figure 3. pH change during the EC process. 


\section{X-Ray Diffraction Analysis}

Diffraction patterns of flocs collected from the experiments with gold and silver, (the samples were ground to a fine powder and loaded into a sample holder) were obtained with a diffracted X-PERT Phillips meters equipped with a vertical goniometer, the XRD scans were recorded from 10 to 70 degrees $2 \theta$ with $0.020^{\circ}$ step-width, and with 10 sec counting time for every step-width. The source of X-rays has a copper anode, whose radiation is filtered with a graphite monochromator $\left(\lambda=1.541838 \AA\right.$ ) with scan rate of $0.02^{\circ}$ and a duration of 10 seconds per count. The X-Ray Diffractometer is controlled by a computer Gatawey 2000, by PC-APD 2.0 software for Windows. Figure 4 shows the ray diffraction pattern of the flocs recovered from a sample of silver, respectively $55 \mathrm{ppm}$, initial pH 8, 20 minutes of treatment. The species identified were magnetite) (JCPDS file 19-629, lepidocrocite (JCPDS file 08-098), and silver (JCPDS file 08-098). The XRD of solid product showed both the well crystalline phases such as magnetite, and the poorly crystalline phases such as lepidocrocite, reason for the decrease of lepidocrocite crystallinity may be due $\mathrm{pH}$ change to 10 , in this point, raise the magnetite formation and decrease the lepidocrocite formation.

\subsection{Scanning Electron Microscopy (SEM/EDAX)}

Figure 5 shows SEM and EDX of silver adsorbed on iron species. SEM microphotography shows that the surfaces of these iron oxide/oxyhydroxide particles were coated with a layer of silver. The chemical composition of solid product as determined by EDX, with this analytical technique used for the elemental analysis or chemical characterization, identify the iron, silver and other elements like calcium and copper, the maximum number of counts from spectrum corresponds to iron and less counts at the other elements include the silver, then we can concluded what the silver is adsorbed on the particle of iron like shows SEM image.

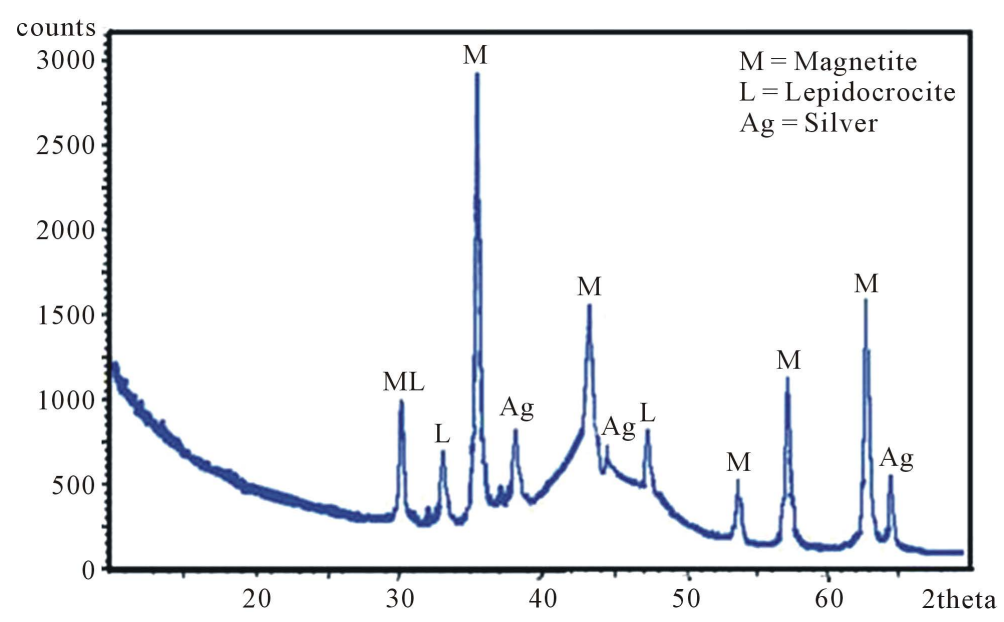

Figure 4. X-ray diffractogram of solids obtained in the recovery of silver from cyanide solutions.

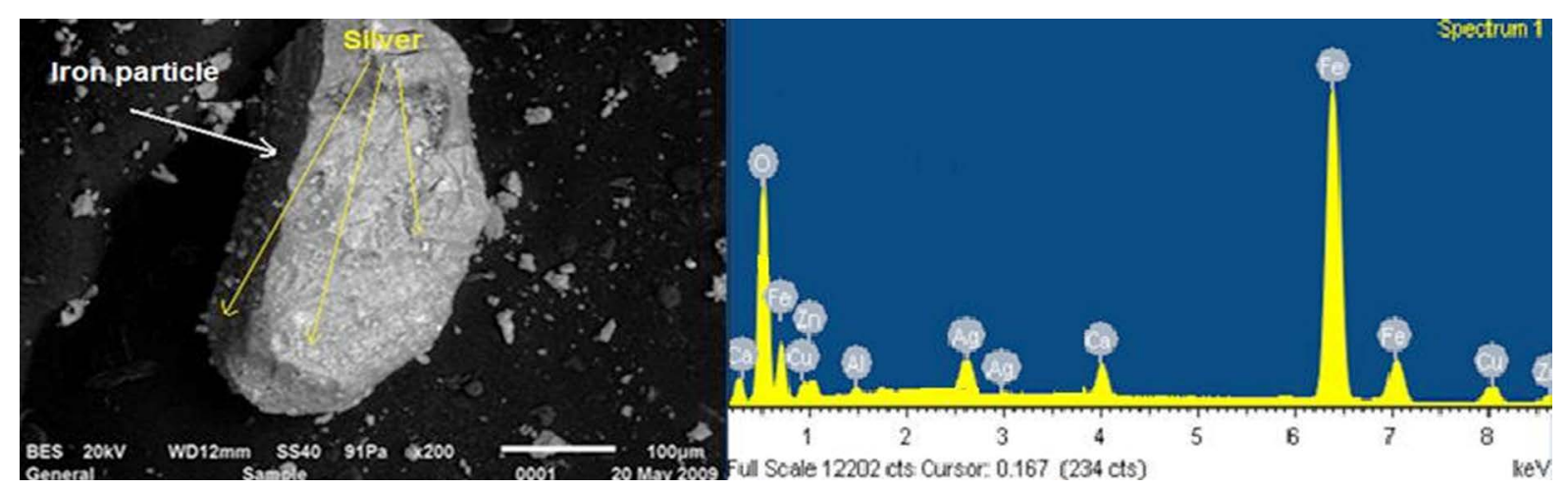

Figure 5. SEM and EDAX images for by-products generated from EC of pregnant solution. 


\section{Conclusions}

The results of this study indicate that silver can be successfully adsorbed on iron species produced by the Electrocoagulation process, so EC may be used to recover silver from cyanide solutions and use this electrochemical process successfully instead of Merrill-Crowe process.

The X-Ray Diffraction, Scanning Electronic Microscopy, techniques demonstrate that the formed species are of magnetic type, like lepidocrocite and magnetite and amorphous iron oxyhydroxide which adsorbed the silver and gold particles on his surface due to the electrostatic attraction between both metals.

The $100 \%$ of silver was recovered in the experimental EC reactor, and it was usually achieved in 20 minutes or less for most experiments with current efficiency of $90 \%$.

\section{Acknowledgements}

The authors wish to acknowledge support of this project to the National Council of Science and Technology (CONACYT) and Department of Chemical Engineering and Metallurgical of University of Sonora.

\section{References}

[1] Parga, J.R., Valenzuela, J.L. and Cepeda, F. (2007) Pressure Cyanide Leaching for Precious Metals Recovery. Journal of Metals, 10, 43-47.

[2] Aguayo, S., Valenzuela, J.L., Parga, J.R. and Lewis, R.G. (2007) Continuos Laboratory Gold Solvent Extraction from Cyanide Solutions using LIX 79 Reagent. Chemical Engineering and Technology, 30, 1532-1536. http://dx.doi.org/10.1002/ceat.200700202

[3] Fleming, C.A., Mezai, A., Bourricaudy, E., Canizares, M. and Ashbury, M. (2011) Factors Influencing the Rate of Golden Cyanide Leaching and Adsorption on Activated Carbon, and Their Impact on the Design of CIL and CIP Circuits. Minerals Engineering, 24, 484-494. http://dx.doi.org/10.1016/j.mineng.2011.03.021

[4] Valenzuela, J.L., Aguayo, S., Parga, J.R. and Lewis, R.G. (2003) Gold Solvent Extraction from Alkaline Cyanide Solutions using LIX 79 Extractant. In: Young, C.A., Alfantazi, A.M., Anderson, C.G., Dressinger, D., Harris, B. and James, A., Eds., Hydrometallurgy 2003—Fifth International Conference, Vol. 1, TMS, Warrendale, PA, 881-889.

[5] Donia, A.M., Atia, A.A. and Elwakeel, K.Z. (2007) Recovery of Gold(III) and Silver(I) on a Chemically Modified Chitosan with Magnetic Properties. Journal of Hydrometallurgy, 87, 197-206. http://dx.doi.org/10.1016/j.hydromet.2007.03.007

[6] Pinga, C.N., Bradshaw, S.M., Akdogan, G., Syniders, C.A. and Eksteen, J.J. (2014) Evaluation of the Merrill-Crowe Process for the Simultaneous Removal of Platinum, Palladium and Gold from Cyanide Leach Solutions. Hydrometallurgy, 142, 36-46. http://dx.doi.org/10.1016/j.hydromet.2013.11.004

[7] Parga, J.R., Cocke, D.L., Valenzuela, J.L., Moreno, H. and Weir, M. (2005) Arsenic Removal via Electrocoagulation from Heavy Metal Contaminated Groundwater in La Comarca Lagunera, Mexico. Journal of Hazardous Materials, B124, 247-254. http://dx.doi.org/10.1016/j.jhazmat.2005.05.017

[8] Parga, J.R., Casillas, H., Vazquez, V. and Valenzuela, J.L. (2009) Cyanide Detoxification of Mining Wastewaters with $\mathrm{TiO}_{2}$ Nanoparticles and Its Recovery by Electrocoagulation. Chemical Engineering and Technology, 32, 1901-1908. http://dx.doi.org/10.1002/ceat.200900177

[9] Mollah, M., Morkovsky, P., Gomez, J., Parga, J.R. and Cocke, D.L. (2004) Fundamentals, Present and Future Perspectives of Electrocoagulation. Journal of Hazardous Materials, 114, 199-210. http://dx.doi.org/10.1016/j.jhazmat.2004.08.009

[10] Emamjomeh, M.M. and Sivakumar, M. (2009) Review of Pollutants Removed by Electrocoagulation and Electrocoagulation/Flotation Processes. Journal of Environmental Management, 90, 1663-1679. http://dx.doi.org/10.1016/j.jenvman.2008.12.011 
Scientific Research Publishing (SCIRP) is one of the largest Open Access journal publishers. It is currently publishing more than 200 open access, online, peer-reviewed journals covering a wide range of academic disciplines. SCIRP serves the worldwide academic communities and contributes to the progress and application of science with its publication.

Other selected journals from SCIRP are listed as below. Submit your manuscript to us via either submit@scirp.org or Online Submission Portal.
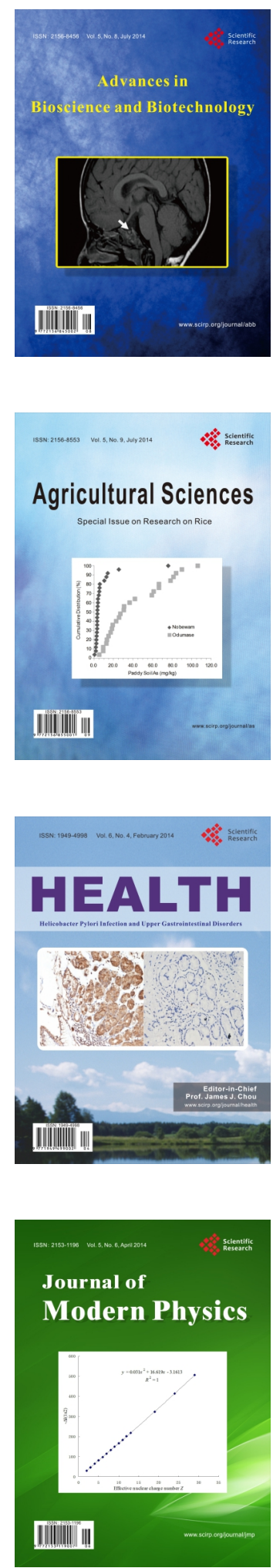
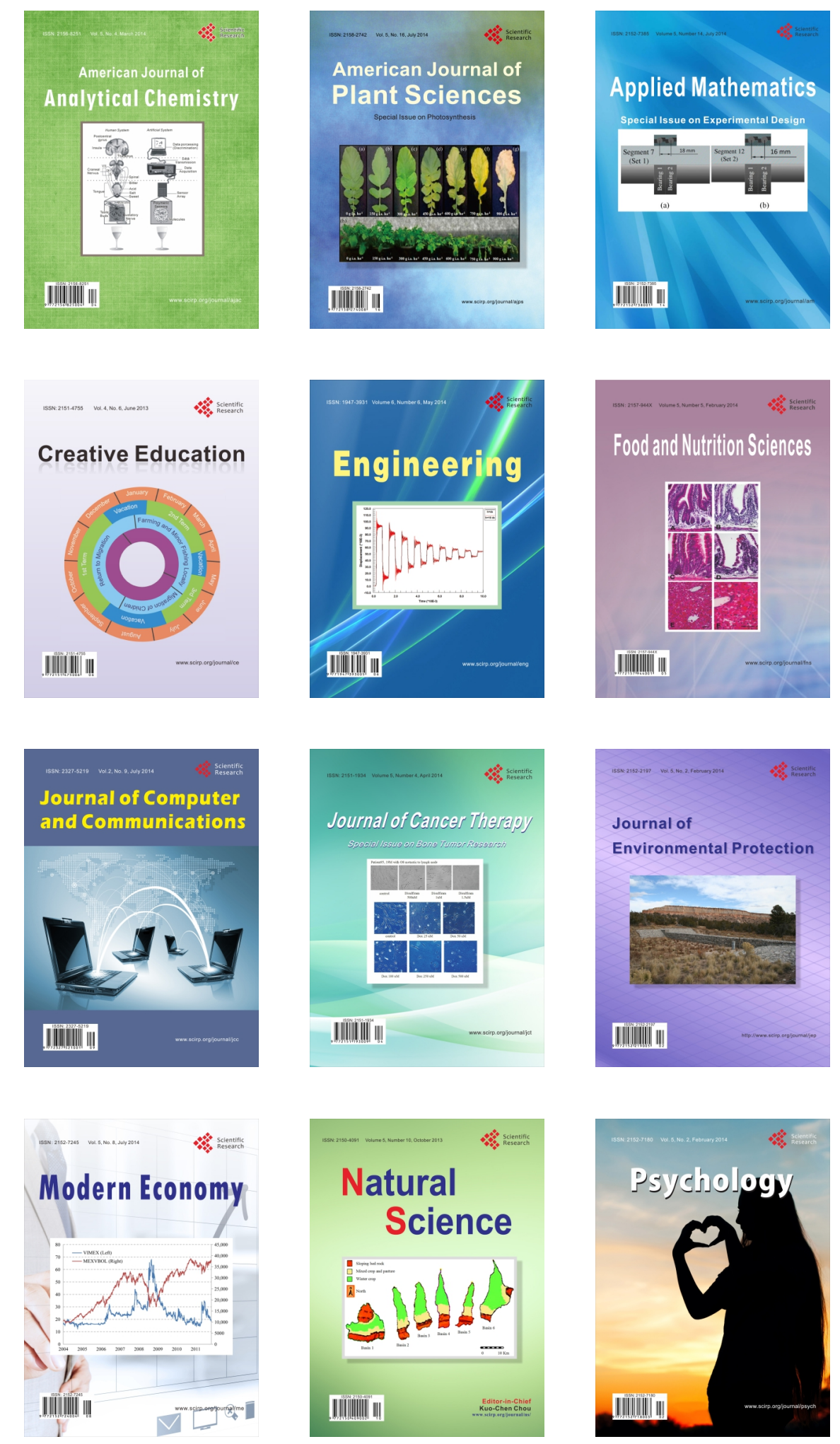